\title{
Journey Towards Self-realization in Nadine Gordimer's The Pickup and Khaled Hosseini's The Kite Runner: A Comparative Study
}

Mohanraj A

Research Scholar (Part-Time)

Virudhunagar Hindu Nadars' Senthikumara Nadar College (Autonomous)

Virudhunagar, Tamil Nadu, India

mohanrajenglish@gmail.com

Dr. A. K. Muthusamy

Associate Professor of English

Research Centre in English

Virudhunagar Hindu Nadars' Senthikumara Nadar College (Autonomous)

Virudhunagar, Tamil Nadu, India

DOI: https://doi.org/10.24113/ijellh.v9i4.10991

Let us go to another country

Not Yours or mine

And start again...

The rest is understood

Just say the word. (William Polmer)

\begin{abstract}
The Prolific South African novelist, Nadine Gordimer's The Pickup (2001) and the promising Afghan writer, Khaled Hosseini's The Kite Runner (2003) belong to New Literatures in
\end{abstract}


English. The main characters in these two novels undertake their journey from their native place to foreign country in pursuit of happiness, place, prosperity and self-realization. This research paper attempts to make a comparison between Gordimer's The Pickup and Hosseini's The Kite Runner in terms of the journey undertaken by the protagonists Abdu and Julie of The Pickup and Amir of The Kite Runner though these two novels are set in a different background.

Keywords: Journey, Self-Realization, Immigrant, Self-Discovery, Comparison

Journey has been a recurring theme found in New Literatures in English. The journey is a powerful symbol often used to represent a character's adventure leading to selfrealization. Moving from one locale to another is a common form of journey. But to creative writers, the journey becomes a metaphorical representation of life. Gordimer and Hosseini successfully takeup journey metaphors and used in their novels to express notions of change and choice, discovery and departure, and search and struggle. As the critic Stephen Hutchinson so succinctly states it, "Life's 'journey' appears to be one of those universal metaphors whose 'diverse intonation' reveals a great deal about how people in different places, times, and persuasions characterize and valorize their own being in the world" (72).

Both Abdu and Amir hail from third world countries. In The Pickup, Abdu's real name is Ibrahim Ibu Musa and an unnamed Arab state is his country of birth. Amir also belongs to one of the Islamic countries as he is born and brought up in Kabul, Afghanistan. Abdu is a graduate in Economics but his country fails to provide him with a suitable job to support his poor family. He criticizes his country because the politicians help the rich from getting richer and the poor becoming poorer. He does not have great regard for his country. He believes that there is "Nothing much to see. It's a village like hundreds of other there, small shops where people make things, cook food, police station, school. The house; A mosque, small. It's very dry -dust, dusty, Sand" (Gordimer 25).Abdu is ashamed of his 
background. He is ashamed of his people's poverty as his country is a desert without opportunities and with a corrupt government. He calls it a "dirty play" and even, a "hell". He goes on journey from his home to a foreign country in search of job and money. Thus, Abdu's journey can be described as materialistic.

Like Abdu, Amir in The Kite Runner, has to travel from his homeland to an alien-land from Kabul to California but for a different reason. Amir has enjoyed his life in his hometown Kabul living with his father Baba and his close friend Hassan. But his happy life is broken into pieces when Russia invades his beautiful and peaceful country, Afghanistan. Many Afghans get killed by Russian soldiers. Some people try to escape from their country with the help of smugglers by moving to some other countries. Leaving his country Amir goes to California as his life is in danger if he stays in Kabul. Thus, Amir's journey can be described as survivalistic. Both Abdu in Johannesburg and Amir in California become immigrants from unknown Arab country and Afghanistan respectively.

Abdu works as a car mechanic in Johannesburg, South Africa whereas Amir gets a degree and enters into writing profession in California. However, both do not have the sense of belongingness and feel 'the Other' for they are treated as inferior beings. For example, Julie's Table Friends of EL-AY Café always refer to Abdu as "Julie's man"or "grease monkey" behind his back [grease refers to his clothes covered in grease as he is a mechanic and monkey indicates of his dark skin - a popular term used by the whites during the racist days]. Abdu does not feel at ease with Julie's friends because their attitude is pretentious and they often indulge in conversation with him to make "a show" of their "conviction of their equal worth" (Gordimer 17). Similarly, Amir is acknowledged as lesser mortal in America. In Kabul, Amir belongs to the upper class and is treated with respect by his people. But in America Amir is considered as lower class. Somehow America is a new place which can hide his past. It allows him blankness, a forgetfulness that will be impossible in Afghanistan. 
Jefferess observes that "Everything he experienced in America sped up his growing up. With different social status, Amir had different experiences in two countries. It helped Amir understand different social values among different classes, races, and more important, humanity" (398). Both Abdu and Amir, the immigrants, are struggling to adjust themselves into a different culture that may not accept their traditions.

Julie Summer, a white South African, is working as a PRO and as a fundraiser in Johannesburg. Abdu helps Julie when her car breaks down in the middle of the street. She finds herself immediately attracted by Abdu and invites him to a café where she introduces him to her circle of Table Friends at the EL-AY Café. Soon they fall in love with each other. Meanwhile, South African immigration authorities send Abdu a letter asking him to leave South Africa as early as possible because they consider his stay in South Africa as illegal. With the help of her father's friend Julie tries to get Abdu a visa to resume his stay but her efforts are ended in vain. He is getting ready to go back to his home country. Julie persuades him to take her along with him. Before they go to the unnamed Arab country, they get married because in the Islamic countries a woman accompanying a man without the bondage of marriage she will be called a "whore" and not a "wife".

Abdu in The Pickup makes his journey back to his native country. Similarly, Amir in The Kite Runner makes his physical journey to his homeland. As Abdu has left no other alternative, he has to travel back home. But Amir's case is completely different. For many years he has been living with guilty consciousness. During his childhood, he had a close friend named Hassan who helped him in winning the Kite fighting tournament. When Hassan was trapped and raped by a local bully, Assef, Amir did not try to help him and he was "just watched. Paralyzed" (Hosseini73). This incident has had a psychological effect on Amir and carried the baggage of guilt with him Amir's indecisive attitude is expressed as "I had one into chance to make a decision. One final opportunity to decide who I was going to be. I 
could step into that alley, stand up for Hassan-the way he'd stood up for me all those times in the past and accept whatever would happen to me. Or I could run" (Hosseini 77). The reason for his running away from the place is expressed as "I ran because I was a coward. I was afraid of Assef and what he would do to me. I was afraid of getting hurt. . . . I actually aspired to cowardice, because the alternative, the real reason I was running, was that Assef was right: Nothing was free in this world" (Hosseini 77).

Amir feels ashamed of not attempting to save Hassan from the brutal hands of Assef and so his mind is filled with guilty consciousness. He wants to get relieved from this agony. The following lines highlight the psychological suffering that Amir has been undergoing:

My chest tightened and I couldn't draw enough air; I'd stand there, gasping in my own little airless bubble of atmosphere. But even when he wasn't around, he was. He was there in the hand-washed and ironed clothes on the cane-seat chair .. . Everywhere I turned; I saw signs of his loyalty, his goddamn unwavering loyalty. (Hosseini 89)

With this guilty consciousness, Amir undertakes his journey to California and becomes a writer.

Amir comes to know about Sohrab, son of his childhood friend, Hassan from Rahim Khan who is the best friend and business partner of his father, Baba. After Russian left Afghan, Taliban took charge of Afghanistan. They killed all the Hazaras, an ethnic minority and in the struggle Hassan and his wife, Farzana got killed and their son, Sohrab was kidnapped by the Taliban. Rahim Khan provides Amir a chance "to be good again" and to clean his act of wickedness. Khan forces Amir to go back to Afghan, find the son of Hassan and adopt him. To expiate his guilt Amir decides to go back to his country again to risk his life in rescuing Hassan's son Sohrab. 
Abdu is happy to marry Julie, but he feels guilty about arriving home with a foreign woman as a wife because he has not earned enough money to give a better life to his mother. Gordimer writes: "He was coming back and it was not as the successful son who had made a better life, the Western life of television version, bringing them a share of it in his pockets and in his person, but as a reject, with nothing but a wife-a foreign woman." (114)Abdu is not happy to stay in his corrupted country. He is very anxious to leave his country to try to get a better job in Australia, Canada and the United States. His aim is to earn more money and send it to "his mother whom he wanted to bring away to a better life" (Gordimer 123).He asks Julie to come with him to America. But she rejects his idea and decided to stay in Arab.

Abdu's wife Julie and Amir's spouse Soraya are also comparable in the sense that they possess similar characteristics. Both remain constant in the face of persistent judgment. Julie strives for happiness in her everyday life by teaching the women and children English in the unnamed Arab Country of Abdu. Similarly, Soraya is happy in pursuing her goal of becoming a teacher in California.

Abdu realizes that there is no meaning in living in his country and leaves his country and goes to America.Similarly, Amir too leaves his country. After a long struggle with the Taliban, he successfully rescues Sohrab, and goes to Pakistan and finally adopts Sohrab, and moves to America. Amir gets redemption for his act of wickedness by saving his friend's son and begins a new life in America.

Thus, Abdu in The Pickup and Amir in The Kite Runner immigrate from their Islamic countries to a foreign country. Though they get a chance to come back to their native countries they are not able to remain there and finally decide to settle in the United States. Journey that they have undertaken plays an important role in their life leading to selfrealization which has allowed them to understand and evaluate their real self, thereby determining their purpose of life. 


\section{Works Cited}

Hosseini, Khaled. The Kite Runner. Riverhead Books, 2013.

Hutchinson, Stephen D. Cervantine Journeys. U of Wisconsin P, 1992.

Jefferess, David. “To be good (again): The Kite Runners allegory of global ethics.” Journal of Postcolonial Writing, vol. 45, no. 4, 20 Nov. 2009, pp. 389-400, DOI:

10.1080/17449850903273572. Accessed 10 Jan. 2021.

Nadine, Gordimer. The Pickup. Bloomsbury, 2002.

Rankin-Brown, Maria. “The Kite Runner: Is Redemption Truly Free?” Spectrum Magazine | Creating Community Through Conversation, 7 Jan. 2008, spectrummagazine.org/node/242. Accessed 10 Jan. 2021. 